\title{
Reflecting on twenty years of Masculinities: an interview with Raewyn Connell
}

\author{
Uma reflexão sobre os vinte anos do livro "Masculinities": \\ entrevista com Raewyn Connell
}

Marcos Nascimento ${ }^{1}$ Raewyn Connell ${ }^{2}$
${ }^{1}$ Instituto Fernandes

Figueira, Fiocruz. Av. Rui

Barbosa 716, Flamengo.

20021-140 Rio de Janeiro

RJ Brasil.

m2nascimento@gmail.com

${ }^{2}$ University of Sidney.

Sidney Australia.

\begin{abstract}
Raewyn Connell is very well known for her work on social theory and gender studies, and more specifically on masculinities. She was one of the founders of masculinities research and her 1995 book Masculinities is considered one of the most important references on the topic. Connell's concept of hegemonic masculinity has been particularly influential and has attracted much debate. She has written extensively about its applications to education, health, and violence prevention. Our conversation was about her trajectory as an intellectual, her commitment to gender justice, and the development of her work from Australia to the global scale.
\end{abstract}

Key words Masculinities, Gender, Global south
Resumo Raewyn Connell é muito conhecida pelo seu trabalho sobre teoria social e os estudos de gênero, particularmente sobre masculinidades. Ela é uma das pioneiras em pesquisas sobre masculinidades e seu livro Masculinities, de 1995, é considerado uma das referencias mais importantes neste tema. O conceito de masculinidade hegemônica desenvolvido por Connell tem sido extremamente influente e gerado muitos debates. Ela tem escrito exaustivamente sobre sua aplicação nos campos da educação, saúde e prevenção de violência. Nossa conversa contemplou temas como sua trajetória intelectual, seu compromisso com a justiça de gêenero e o desenvolvimento do seu trabalho a partir da Austrália para uma escala global.

Palavras-chave Masculinidades, Gênero, Sul global 
Marcos: Tell us about your academic trajectory.

Raewyn: I am from Australia, a remote, dry continent. Australian Aboriginal culture goes back about 50,000 years; it is probably the oldest continuously existing culture in the world. The country was colonized by the British a mere 200 years ago, and became a settler colony. My family has been in Australia for about 150 years. My social background is mixed but relatively privileged, ranging from the fringes of the upper class to poor middle class. I have had a career in the university world, so I have maintained that class position in my own life.

In world terms, Australian settler society was a remote colony with a very limited intellectual life, until fairly recently. I studied History and Psychology as my first degree, and Political Science as my second degree. I was one of the first generation to get a $\mathrm{PhD}$ actually in Australia. Previous generations of academics had gone to the metropolis that is to Britain, to get higher degrees, and to some extent to the United States. When I was a student, we were just at the stage of developing a research capacity in Australia.

That time also corresponded with the rise of the student movement. I was an activist in the New Left in the 1960s and 70s, involved in the struggle against Australian participation in the war in Vietnam. I was also very much involved in intellectual struggles in the late 1960s. I was involved in a group of young people setting up what we called the Free University in Sydney. We had the idea of creating a radical education center outside the existing universities. It did not last long but it was very exciting!

I then went into mainstream academia. I had the idea, like many people at the time, that we could transform universities from inside, that we could make them more progressive, more useful for social justice and social transformation. The official universities were elitist, upper class institutions when I began, but that was changing in the 1970s. I became head of a new Department of Sociology, at a newly founded university, Macquarie University in Sydney. We were able to develop new curricula, new pedagogy, and work with new groups of students, especially women, whose numbers were rising in universities at the time.

We did not achieve anything like the institutional transformation we had hoped for. But over a period of fifteen or twenty years, from the late 1960 s to the 1980 s, we did in fact launch many new knowledge projects - what we imagined as a new kind of social science, with an orientation to social justice struggles, and concerns to speak to a wider audience. An important part of that was social research on gender.

Marcos: You are very well known for your work on gender, more specifically about men and masculinities. How did you develop your interest in this subject?

Raewyn: In earlier times, universities simply ignored gender as an intellectual issue. In the Macquarie University we made it a major theme in both teaching and research. In my own work in the 1970s gender was particularly connected with education. I was involved in progressive education efforts both practically and in research. At first, I was not involved in health research, though other colleagues and students were, especially through the network of women's health centers and shelters that was set up in Australia during the 1970s.

I was not part of the Women's Liberation movement because I was living as a man at the time, but my partner Pam Benton was a feminist activist, and so were other women I worked with. When I began thinking seriously about gender as a research issue, feminist questions about power, patriarchy and their legitimation were very central concerns. It is also relevant that I had been doing a lot of research and political work on class issues. I was an active member of the Labor Party then, and I was involved in research and action about class inequalities in schools. I studied Gramsci and tried to adapt some of his ideas about hegemony and cultural struggle. My best-known book in the 1970s was called Ruling Class, Ruling Culture ${ }^{1}$.

In the late 1970s, I began to apply this kind of power analysis in the study of gender. I was not satisfied with the concept of "patriarchy" as an abstract structure. The idea had to become more concrete, more practical. I wanted to know: who were the patriarchs? How did the structure work? Who made it operate? Essentially that was how I came to formulate problems about masculinity.

In the very early 1980s, we were analyzing data from our research on social inequalities in schools. We had interviewed teenage boys and girls, their teachers, their parents, mothers and fathers in their homes ${ }^{2}$. The gender issues were very clear, and we had a lot of information about the boys and the fathers, as well as the girls and the mothers. That was where the concept of "hegemonic masculinity" came from. We were looking at gender relations in schools, at hierarchies 
and exclusions, and the pattern of hegemony leaped out at us. There were different masculinities, there were hierarchical relationships, there was contestation, and there were dilemmas about how hegemony was maintained in changing economic circumstances.

As we published the work from that education study, I was thinking about the concepts we used, and decided we really needed a better social theory of gender. There were sophisticated sociological theories of class, but not of gender. So, I applied for a research grant, and got it - I think the first research grant for social theory in Australia! That provided a job which was shared by two activists from the Gay Liberation movement, Tim Carrigan and John Lee. We planned the project as a step-by-step exploration of issues, and we began with the question of men and masculinities. For me, this was the way to theorize patriarchy; for them, it was the way to theorize homophobia and the domination of straight men over gay men. We began work on that problem, and it took over the whole project! We wrote a long article outlining a theory of multiple masculinities and hegemony ${ }^{3,4}$. It synthesized concepts from feminism, gay liberation, psychoanalysis, and sociology. We could not get it published in Australia, so I sent it to a North American journal, and to their eternal credit, they published the whole thing. Then it was read and translated and circulated internationally. After that, I thought that we have the theory, but what about the data? Being a good empiricist, I started a new phase of research, doing life-history studies with different groups of men. I published these as a series of articles 5 . I was reluctant at first to write a book about masculinity.

\section{Marcos: Why?}

Raewyn: Because at the time, there was a whole genre of books about masculinity, like Robert Bly's book Iron John ${ }^{6}$, that claimed men were suffering from a crisis of masculinity and needed to recover 'true masculinity'. They were totally unscientific, but very popular. I came to think of them as masculinity therapy, books to reassure men so they could function as patriarchal once again. I did not want to be part of that! I thought that yet another book about men and masculinities would simply reinforce this trend. At much the same time that Judith Butler in Gender Trouble $^{7}$ was criticizing essentialist ideas about femininity and women, I was grappling less effectively with essentialism about masculinity.
Eventually I did persuade myself to write a book. I was in America at the time, as a visiting professor at Harvard University. I took it to one of the leading American publishers and said 'Have I got a book for you!' They turned it down. However, another publisher did accept Masculinities ${ }^{8}$, it appeared in 1995 and has been widely read. There are something like 15000 citations of its editions recorded by Google Scholar. It has now been translated into ten languages from the original English.

Marcos: You talked about the link between masculinity and education. What has been your experience on the link between masculinity and health?

Raewyn: In the mid-1980s, when we were publishing our theoretical work on gender, the gay community in Sydney, the biggest gay community in Australia, was feeling the early impact of HIV/ AIDS, and people were beginning to die. My colleagues were very affected by this. The leading gay group concerned with prevention, safe sex and community education came to me and said, "We need a research base about sexual practices, can you do this for us?"

We formed a research team, got federal government money, and launched a large quantitative and qualitative research project on gay men's sexual practices in their social context. We combined social theory, research methodology and grassroots activism in a way that was not being done at the international level. Like our education research, this was done in very close association with the people who would use the knowledge we produced. It was an example of the new social science we had been trying to create in the 1970s, combining intellectual power and democratic practice - at least we hoped so! As our results came out of the computers, we fed them straight to the community educators in reports and workshops, so there was constant feedback and interaction. It was a very exciting, as well as frightening moment. That project launched the main Australian social research agenda on the epidemic, which became the national center headed by Sue Kippax. That was my first work on health questions. In the late 1990s, when I was at the University of Sydney, I worked with a different research group to create a national report on men's health research ${ }^{9}$. More recently, I have worked on conceptual questions about embodiment and health. That work has produced papers concerning Southern perspectives on dis- 
ability, and how we should theorize gender and health ${ }^{10,11}$.

Marcos: Your work on masculinities has led you to participate in different areas on gender equality, right?

Raewyn: The question of gender-based violence, like the question of education, led me to think about how the sociology of masculinities could be used in social policy. In the 1990's I was invited to join discussions in Unesco about masculinity, gender and violence at a societal level. This produced a book ${ }^{12}$ and a string of articles. I have been concerned with the issue ever since. It required thinking on a much larger scale than the work we did with the gay community - more abstract, and probably less effective in practice. But it led to my involvement with United Nations agencies concerned with gender equity. In 2003-4 I worked with them on a global survey of research about men's role in achieving gender equity, and this covered many policy fields, from education to employment as well as violence. It led to the first international policy guidelines on this subject, a document I helped to draft, which was issued by the United Nations Commission on the Status of Women in $2004^{13}$.

Marcos: And you have been working on SouthSouth collaboration, haven't you?

Raewyn: The story I am telling you is very centered in Australia, not in London or New York. In Australia, we are always grappling with questions of marginality, intellectual dependence, and autonomy - as I think you do in Brazil. Academically, questions about masculinity began to circulate through US journals originally, and then in European journals. The Australian context of my work was hardly noticed - I was often assumed to be American! In the early 1990s, our research began to appear and be noticed in the international literature in a substantial way. By then I was getting invitations to speak at conferences in the global North.

That brought me in touch with many masculinity researchers, sexuality researchers, and education researchers in Germany, Britain, Scandinavia, Canada, and the United States. I began to understand the way the global economy of knowledge worked. When we published research in Australian journals, no one in the rest of the world noticed. When we published in northern journals, our work would be read in South
America, India, Japan, Africa, etc. In a weird way, we began to make South-South connections through the North.

I then tried to develop connections with colleagues around the Global South - travelling to speak at conferences, making some longer academic visits, collecting texts, and trying to learn some Spanish and Portuguese. This led to collaborative research, some concerned with masculinities and some with intellectuals, another research interest of mine

A major product of this work was my book Southern Theory ${ }^{14}$, which looks at social analysis in the colonial and postcolonial world and spells out an agenda for social science on a world scale. Nothing if not ambitious! Concerning gender, a major product was a three-country research project on managerial masculinities ${ }^{15}$. More recently, I have been working on gender theory from around the Global South. Some of that is in my very latest book, just published in Portuguese ${ }^{16}$.

Marcos: After 20 years of Masculinities, how do you see the men's studies field? Is there a men's studies field?

Raewyn: I never wanted to have a 'men's studies' field. As you can see from my story, I became interested in masculinities while trying to understand educational inequality, gender dynamics, dynamics of power, and change in gender relations. For me, research on masculinities, and studies of men as bearers of masculinity, have always been part of a wider field of knowledge.

As I mentioned earlier, I was worried about the essentialism that appeared very early in discourses about masculinity. That is a serious risk in constituting a field of "men's studies". It tends to isolate the issues about men, and forget that gender is always relational. It can end up, implicitly, as a defense of men's privilege. Because the whole domain of gender analysis involves structures of power, inequality and violence, we must be concerned with the political effects of the way knowledge is organized.

I worry about the tendency to make separate fields out of men's studies, women's studies, queer studies, sexuality studies, transexuality studies. When Tim Carrigan, John Lee, and I put together our original theory, we included a current of arguments from Gay Liberation. It was gay men, I think, who first began to unpack masculinity as a system of exclusions and polarizations. But, it was connecting their ideas with feminist research on institutionalized power, culture and social- 
ization that was the key to a powerful analysis of masculinities.

The development of research on men and masculinities helped the transformation of women's studies into gender studies. That has been a contested change; many feminists feared it would depoliticize the field, and broadly, they were right. Women's studies was a militant project. It was saying that we are in a patriarchal world of knowledge, which has been dominated by men. There is a vast area of unrecognized knowledge about women's lives and women's perspectives, and that knowledge requires a social movement in the intellectual world to develop and establish. Now, gender studies and men's studies can be political, but they do not represent the same kind of insurrection. They can be just another specialty, another subdivision in the landscape of knowledge, politically inert.

Marcos: Do you see the studies of men and masculinities as a political action as well?

Raewyn: Yes, but it is not necessarily the kind of politics you would want! There is a spectrum of possibilities. Men's studies can be set up as a depoliticized intellectual project. In the late 1970s and 80 s there was an attempt to map the history of men, or the history of masculinity, that way. The field can also be set up as a defense of men's interests. By the 1990s, "men's rights" polemicists in the United States were complaining that women had unfair privileges, that boys were being oppressed by feminism etc. Researchers sympathetic to this line began producing catalogues of men's disadvantages and sufferings, and this still goes on.

Yet it is also possible to set up a field of research and analysis that explores men's lives, actions and experiences in the wider context of the gender order. A relational understanding of masculinities informs projects of change, and struggles for gender equality, which already are expanding the emotional possibilities for men in workplaces and in families. The political Right sees gender change as a zero-sum game - when women gain, men must lose - and tries to mobilize men (and fearful women) against gender equality. But, gender does not have to be a zero-sum game.

Marcos: Has this focus of research changed?

Raewyn: It has certainly grown as a field of knowledge. The expansion of numbers of publications, in the 1990s especially, was quite remarkable. It has become genuinely a worldwide research field. Concepts have also changed. The idea of a single normative "male sex role" was the dominant discourse in the 1970s and 80s. Twenty years later the male role had not exactly vanished, but role theory was much less central to the field. There was now greater recognition of the complex structure of gender relations, the local diversity of masculinities, and the multiplicity of masculinities. I think that my work was helpful in giving people ways of understanding that. The concept of "hegemonic masculinity" is often misused, becoming a kind of surrogate role theory. We should always be aware that there are other kinds of masculinity too! And some alternative masculinities - such as we see with many young fathers becoming seriously engaged in care for young children - are wonderful to see.

Marcos: Thank you!

\section{Collaborations}

M Nascimento and R Connell worked on the design and final editing of this paper. 


\section{References}

1. Connell, R. Ruling Class, Ruling Culture: Studies of Conflict, Power and Hegemony in Australian Life. American Journal of Sociology 1979; 84(5):1313-1315.

2. Connell R. Estabelecendo a Diferença: Escolas, Famílias e Divisão Social. Porto Alegre: Artes Médicas; 1995.

3. Carrigan T, Connell R, Lee J. Toward a new sociology of masculinity. Theory and Society 1985; 14(5):551-604.

4. Connell R. Masculinities in Global Perspective: Hegemony, Contestation, and Changing Structures of Power. Theory and Society 2016; 45(4):303-318.

5. Connell R. A very straight gay: masculinity, homosexual experience and the dynamics of gender. American Sociological Review 1992; 57(6):735-751.

6. Bly R. Iron John: A Book about Men. Boston: Addison-Wesley; 1990.

7. Butler J. Gender Trouble: Feminism and the Subversion of Identity. New York: Routledge; 1990.

8. Connell R. Masculinities. Cambridge: Polity Press; 1995.

9. Connell R, Schofield T, Walker L, Wood J, Butland D. Men's Health: A Research Agenda and Background Report. Canberra: Commonwealth Department of Health and Aged Care; 1999.

10. Connell, R. Southern bodies and disability: re-thinking concepts. Third World Quarterly 2011; 32(8):13691381.

11. Connell R. Gender, health and theory: Conceptualizing the issue, in local and world perspective. Soc Sci Med 2012; 74(11):1675-1683.

12. Breines, I, Connell R, Eide I, editors. Male Roles, Masculinities and Violence: A Culture of Peace Perspective. Paris: UNESCO; 2000.

13. Lang J, Greig A, Connell R. The Role of Men and Boys in Achieving Gender Equality. New York: UN Division for the Advancement of Women; 2008.

14. Connell R. Southern Theory: The Global Dynamics of Knowledge in Social Science. Cambridge: Polity Press; 2007.

15. Olavarría J, editor. Masculinidades y globalización: Trabajo y vida privada, familias y sexualidades. Santiago: Red de Masculinidad/es Chile, Universidad Academia de Humanismo Cristiano, CEDEM; 2009.

16. Connell, R. Gênero em termos reais. São Paulo: nVersos; 2016.

Artigo apresentado em 30/09/2016

Aprovado em 04/10/2016

Versão final apresentada em 06/10/2016 